\title{
Genital Molluscumcontagiosum Transmitted by a Sandbag
}

\author{
Habibullah Aktaş \\ AssistantProf., Karabük Education and Research \\ Hospital, Department of Dermatology, Karabük, \\ Turkey \\ aktashabib@hotmail.com \\ Aytaç Bilgiç \\ Specialist, Karabük Education and Research \\ Hospital, Department of InfectiousDiseases, \\ Karabük, Turkey \\ a_bilgic@gmail.com
}

\section{Can Ergin}

Specialist, Dışkapı Yı1dırım Beyazıt

EducationandResearchHospital, Department of Dermatology, Ankara, Turkey drcanergin@hotmail.com

\section{Adem Adar}

Specialist, Karabük Education and Research Hospital, Department of Cardiology, Karabük, Turkey a.adar@yahoo.com

\section{Orhan Önalan}

Specialist, Karabük Education and Research Hospital, Department of Cardiology, Karabük, Turkey orhan_73onln@gmail.com

Keywords: molluscumcontagiosum, contamination, transmission, sandbag

\section{SUMMARY}

Molluscumcontagiosum is a skin infection caused by the molluscumcontagiosum virus. The routes of transmission aredirect contact, autoinoculation, or sexual relation but sometimes the virus can be transmitted via shared materials such asbathroom fixtures or towels. Herein, we report a case of 52year-old man with genital molluscumcontagiosumpossibly infected by a contaminated sandbag.

\section{CASE Report}

A 52-year-old man presented with a gradually increasing number of papules in the pubic region. He had undergone cardiac catheterization via femoral access 4 months earlier and the first papules developed 2-3 weeks after that procedure. The dermatological examination showed multiple umbilicated translucent papules in the right pubic region (Figure 1). He denied having had any sexual relations, including with his wife, for at least 6 months. He had poorly controlled diabetes mellitus and coronary heart disease. Upon questioning him about possible causes of contamination after rejecting a venereal route, we learned that a sandbag had been put over his pubic area to maintain hemostasis after the femoral catheterization. Apart from sexual contact, we inquired about other suspected routes of contamination, such as home materials (e.g., towels), but nothing was identified. The disease appears to have been contracted via a sandbag contaminated through contact with previous patients. The patient was diagnosed with molluscumcontagiosumbased on the history and typical clinical lesions. He was treated successfully with cryotherapy.

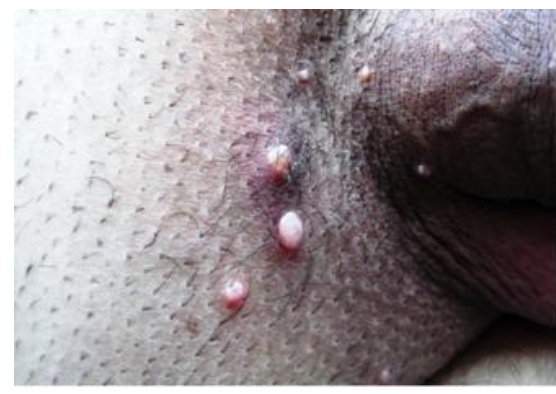

Figure1. Typical Umbilicatedpapular Lesions of Molluscumcontagiosum 


\section{DisCUSSION}

Molluscumcontagiosum is a skin infection caused by the molluscumcontagiosum virus, a DNA poxvirus. It primarily affects children, and occasionally adults and immunocompromised persons. Molluscumcontagiosum is easily diagnosed by its characteristic umbilicated papules. Lesions usually occur on the trunk and extremities and rarely in the genital region. The main modes of transmission are direct contact, autoinoculation, or sexual relations in adults (1).

Although the contamination route is almost always sexual contact, when genital molluscum occurs in relation with a medical intervention it may also be regarded as a healthcare infection, since medical procedures in the 30 days prior to an infection are accepted as a cause in the definition of healthcareassociated infection (2). Our patient had no risk factors except sandbag contact after his femoral catheterization during coronary angiography. He definitely denied any sexual contact, even with his wife, for at least 6 months before the lesions appeared. The patient stated he had very low sexual desire and erectile capability because of his ongoing illnesses.

Genital molluscum is sometimes transmitted via bathroom fixtures or towels or similar materials (3). The possibility of transmission other than through sexual contact via shared materials supports our hypothesis that sandbag contact after femoral catheterization may transmit the microorganism.

The noninvasive transmission of infection via shared materials is not new. In 1969, an arm cuff used for blood pressure measurement reportedly played an important role in the transmission of microorganisms from person to person (4). A case of molluscumcontagiosum after a tattoo procedure probably resulted from contaminated needles or ink (5). A surface contamination study done in a medical center detected human papilloma virus (HPV) particles in treatment rooms and toilets, where they were spread via contaminated gloves (6). Patient examination tables, light switches, door handles, hot bags, and closet seats carried HPV particles in another study (7).

It is possible and easy to ensure that each patient comes into contact only with sterilized or disposable medical materials such as sandbags in busy medical centers. If no care is taken, a contaminated unsterilized sandbag may eventually cause genital molluscumcontagiosum, normally a sexually transmitted disease, as was the case with our patient.

\section{Conclusion}

Although molluscumcontagiosum can be treated successfully, this case demonstrates the importance of meticulous sterilization of all medical materials since unsterilized or non-disposable medical materials carry a risk of contamination with infectious diseases, such as human immunodeficiency virus or hepatitis $\mathrm{B}$ or $\mathrm{C}$ virus. It is vitally important to use patient-specific or sterilized medical materials.

\section{REFERENCES}

[1] Zhuang K, Ran Y, Xu F, Lama J. AtypicalinfantilegenitalMolluscumcontagiosum. An BrasDermatol. 2015;90:403-5.

[2] Cardoso T, Almeida M, Friedman ND, Aragão I, Costa-Pereira A, SarmentoAE, et al.Classification of healthcare-associated infection: a systematicreview 10 yearsafterthe firstproposal.BMC Med. 2014;12:40

[3] Choong KY,Roberts LJ. Molluscumcontagiosum, swimmingandbathing: a clinicalanalysis. Australas J Dermatol.1999;40:89-92.

[4] Beard MA, Mclntyre A, Rountree PM. Sphygmomanometers as a reservoir of pathogeni cbacteria. Med J Aust.1969;2:758-60.

[5] LucianaMolina. RicardoRomit.Molluscumcontagiosum on tattoo.An BrasDermatol. 2011; 86:352-4.

[6] Strauss S, Sastry P, Sonnex C, Edwards S, Gray J.Contamination of environmentalsurfaces bygenitalhumanpapillomaviruses.SexTransmInfect. 2002;78:135-8.

[7] SStrauss, H Stephen, C Sonnex, and J Gray. Contamination of environmentalsurfaces bygenitalhumanpapillomaviruses (HPV): a followupstudy.SexTransmInfect. 2003;79:426-7. 